Eukasz Wiraszka (D)

Jagiellonian University in Kraków

lukasz.wiraszka@uj.edu.pl

\title{
Viewpoint in Translation of Academic Writing: An Illustrative Case Study
}

\section{Introduction}

The idea of employing the concept of viewpoint in linguistic research on academic prose and its translation may seem rather peculiar. After all, there is a whole range of text types where traces of authorial presence are the usual suspects, with the research article or the university textbook typically thought of as representing the opposite end of the scale, i.e. paradigm examples of "objective" expression of thought. However, as noted by Hyland [2005b: 173], "academic writing has gradually lost its traditional tag as an objective, faceless and impersonal form of discourse" and, as a result, the authorial viewpoint imprinted in the fabric of an academic text has in recent years become the subject of a growing number of studies [e.g. Charles 2003; Silver 2003; Biber 2006; Hyland and Sancho Guinda 2012; Aull and Lancaster 2014; Bruce 2016]. Some researchers of academic discourse have even gone so far as to suggest that its aim is "to persuade the reader to accept the author's viewpoint" [Gray and Biber 2012: 23]. It follows, then, that examining equivalence of viewpoint between source and target texts should fall within the 
purview of research on translation of academic writing. Yet, viewpoint phenomena in academic texts have received scant attention in the translation research published to date.

The purpose of this article is therefore to offer a short case study illustrating viewpoint shifts that can occur in the translation of academic prose, which will, hopefully, demonstrate that research on translation could benefit from exploring the ways viewpoint is expressed in source and target texts of this type. The discussion will be based on examples from an English monograph on Cognitive Linguistics and its Polish translation: John R. Taylor's Linguistic Categorization [1995], translated into Polish as Kategoryzacja w jezzku [2001]. Even though a preponderance of studies on viewpoint in academic prose focus on research articles, ${ }^{1}$ which is hardly surprising given the status of this genre as the basic medium for the dissemination of research results, the present study uses material from a monograph for one basic reason: the monograph is, besides the university textbook, one of the most frequently translated academic genres and, unlike the latter, it is directed at fellow scholars.

The article is structured as follows: the next section provides a brief overview of the major understandings and applications of the concept of viewpoint in studies of text and translation. Section 3 outlines a model of the category developed specifically for academic writing. In section 4 , a number of translation examples are analyzed to illustrate different types of viewpoint phenomena subsumed in the model. The concluding section provides a short summary, indicates the implications, and suggests possibilities of future research.

\section{Viewpoint as a theoretical construct}

The concept of viewpoint, or point of view, was first used in literary studies, and there it has gained by far the widest currency, where it has mostly been employed to account for different styles of narration in prose [e.g. Booth 1961; Banfield 1982; Fowler 1986; Ehrlich 1990]. Several components of the category have been distinguished, with the most obvious one relating to the literal sense of the term, i.e. the position in space occupied

1 This is not to say that other academic text types receive little attention; on the contrary, researchers' interest in other "academic registers," both written and spoken, has been on the increase in the last several years (e.g. Biber 2006; Bruce 2016; Hyland 2012; Thompson 2003; Tse 2012). 
by the speaker (or the narrator in literary prose), from which he or she observes and recounts the perceived events. The spatial aspect of viewpoint is represented in text with deictics, such as the adverbs here/there, the demonstratives this/that, and prepositional expressions like in front of/ behind or above/below. Since their use depends on the speaker's location in space, they can serve as clues as to the speaker's point of view relative to the things described in an utterance.

The spatial dimension of viewpoint has an analogue in the domain of time, which represents another component of the category. The speaker's location on the axis of time is reflected in language by the system of tense and adverbials of time, such as now/then, yesterday/today/tomorrow or ten years ago / in ten years. In a literary narrative, temporal viewpoint plays a crucial role in indicating the relationship between the time of the recounted events and the time at which narration takes place and, as such, it can be employed to signal "flashbacks, gaps in the progression of time, and the interweaving of other stories and incidents which break up the linear development of the main body of the narrative" [Simpson 1993: 11-12].

A third aspect of viewpoint is related to the speaker's knowledge, which in literary prose translates into the narrator's knowledge of, or access to, a character's feelings, perceptions and thought processes, and is therefore sometimes referred to as the "psychological plane." The types of psychological viewpoint in literary narration include: subjective first-person narration; omniscient third-person narration with access to the characters' minds; restricted third-person narration, describing externally perceived states of affairs only; and external narration with the narrator voicing his or her own opinions about the characters [Simpson 1993: 35-38]. Apart from the grammatical category of person, this dimension of viewpoint is also connected with the use of epistemic modality to verbalize the narrator's conjectures about the characters' internal states. The last type of literary narration mentioned above illustrates yet another dimension of viewpoint often distinguished in linguistic studies of literary narration, viz. one connected with personal opinion and evaluation, sometimes referred to as "ideological" viewpoint. Thus, viewpoint is a complex semantic category, in most approaches comprising at least four different aspects and, as noted by McIntyre, it "continues to be a central concern in the stylistic analysis of prose fiction today" [2006: 1].

Apart from literary prose, the concept of viewpoint has also been applied in various other areas of study, including film [Branigan 1984], 
drama [McIntyre 2006], conversation [Scheibman 2002; Englebretson 2007], news reports and advertisements [Simpson 1993], political discourse [Guilbeault 2017], and multimodal communication [Dancygier and Sweetser 2012; Dancygier 2017], to name just a few. Incidentally, the latter three studies largely represent a Cognitive Linguistics approach, which adopts a broader conception of the category in question.

The notion of viewpoint itself is one of the constructs employed to describe semantic structure in Langacker's Cognitive Grammar (CG), with its central element (vantage point) being the place from which a situation is observed (or conceptualized), a sense of viewpoint akin to the spatial use of the concept outlined above [cf. Langacker 1987: 123]. As in the analysis of literary narration, Langacker's notion of viewpoint is also applied to domains other than space, such as time or knowledge. Moreover, in Langacker's approach, the viewpoint invoked by a linguistic expression does not have to be the actual place that the speaker occupies at the time of the speech event. Through the process of mental transfer (or, more generally, mental simulation), the speaker can imagine what a particular situation would look like from another location or another person's vantage point [Langacker 2008: 547]. This ability can lead to the expression of the interlocutor's viewpoint, as in: I'm coming (as opposed to I'm going) or a "fictive viewpoint," as in: If it was April 10 today, it would be my birthday tomorrow. What is also worth noting, CG appreciates that certain instances of language use are indicative of conceptualizations involving "fictive" or "subjective" motion of the conceptualizer's viewpoint, as in: The road turns left and runs down to the village ${ }^{2}$ [cf. Langacker 1987: 175]. Finally, the notion of viewpoint in CG is said to be a "virtual" phenomenon since the person viewing the scene described by a given linguistic expression, i.e. the conceptualizer, "cannot in general be identified with any particular individual" [Langacker 2008: 448]. Although the default conceptualizer is the speaker, this is liable to change in the course of discourse and it is often impossible to determine whose viewpoint is being expressed solely on the basis of the linguistic form used. That is why any analysis of viewpoint requires - apart from examining individual expressions and grammatical structures - interpreting the content, structure and logic of the text, which makes it impossible to set

2 In this example, the conceptualizer mentally follows the course of the road (or simulates the travel). 
forth an all-inclusive and definitive repertoire of the linguistic markers of viewpoint [cf. Tabakowska 2004: 62].

As regards translation, studies comparing viewpoint phenomena in source and target texts represent an "almost new" line of research [Lu and Verhagen 2016: 170], with most studies to date focusing on viewpoint in translation of literary texts. Tabakowska [1993] has done pioneering work in this area, employing the CG methodology to analyze viewpoint phenomena (connected with, among other things, the use of English articles, tense and sentence structure) in translations (and originals) of literary texts. Her meticulous linguistic analyses (also proposed in more recent studies, e.g. Tabakowska 2004, 2014), reveal changes, or "shifts," of viewpoint, in translation and, in some cases, demonstrate the impossibility of attaining an equivalent viewpoint in the target text due to differences between the source and target language systems. Several other scholars have also been concerned with tracking viewpoint in translations of literary prose, whether adopting a Cognitive Linguistics approach [e.g. Cierpisz 2007; Foolen and Yamaguchi 2016; Lu and Verhagen 2016] or following Baker's [1996] corpus-based approach to the study of translation combined with Simpson's [1993] model of the category [e.g. Bosseaux 2007].

The above-mentioned shifts of viewpoint in translation can be regarded as resulting from what Lewandowska-Tomaszczyk [2010] refers to as a "re-conceptualization" of the source-text message. Based on the CG view that linguistic meaning is conceptualization, understood broadly as the language user's mental experience associated with a particular linguistic form, the researcher argues that the translated text represents "a third cycle of re-conceptualization", with the first one (the original conceptualization) identified with the author of the original and the second one being the translator's own conceptualization of the message in the source text [2010: 108]. In this approach, re-conceptualization, which typically involves a different construal of the situation described in the source text, is seen as "not only possible but unavoidable in translation," and as such it can be a consequence of three factors: different linguistic resources (evoking a different construal) in the target language, a different context in which the target text functions, and "subjective preferences of the translator in choosing particular target language forms" [2010: 108]. Importantly, the typology of re-conceptualization-related shifts proposed by Lewandowska-Tomaszczyk includes, among other things, viewpoint 
shifts (understood narrowly, in the deictic sense) and shifts in "axiological markedness," both of which are subsumed under the model of viewpoint adopted for the purposes of the present study.

Some research on viewpoint has also been reported in the field of interpreting, mostly focusing on particular components of the category. For example, Warchał and Łyda [2009] offer a study of epistemic modality in consecutive interpreting. A more extensive analysis of viewpoint shifts in (consecutive and simultaneous) interpreting, based on the tenets of Cognitive Linguistics, is presented in Wiraszka [2015]. Research on viewpoint in the translation of academic or popular science prose is even more scant, with the few existing studies focusing on a single aspect of viewpoint only, mostly hedging [e.g. Pisanski Peterlin 2010; Kranich 2011], but also authorial self-mention [e.g. Pisanski Peterlin 2008] and evaluation [e.g. Chen 2012]. Therefore, the case study offered in the present article seeks to substantiate the need for a more comprehensive approach to the study of viewpoint phenomena in the translation of academic texts.

\section{Viewpoint in academic discourse}

There appears to be a growing consensus among researchers investigating academic texts that, as observed by Silver [2003: 362], statements made by authors of such texts "are never simply "matter of fact'." On the contrary, as Hyland [1998: 2] put it, authors "cannot avoid encoding their point of view towards whatever they say, commenting on committing or distancing themselves from their propositions." Despite this general agreement, however, the labels attached to the subjective aspects of text are many and various. Examples include appraisal, evaluation, evidentiality, hedging, modality, posture, stance, subjectivity, and viewpoint [Sancho Guinda and Hyland 2012: 1; cf. Gray and Biber 2012: 16]. Importantly, this broad range of terms reflects the multiplicity of the models proposed to classify and describe the different ways in which viewpoint can be expressed in a text. Since providing an overview of them all would go beyond the scope of the present study, ${ }^{3}$ we will only consider a model proposed by Hyland [2005b] specifically for academic writing. Because it represents a functional approach, offering a cross-linguistic validity that makes it suitable for the investigation of viewpoint in translation, the

3 For a succinct discussion of the different approaches, see Gray and Biber (2012: 15-19); also, see Silver (2003). 
model will be employed in section 4 to illustrate viewpoint shifts in the translation of academic material. ${ }^{4}$

Centered on writer-reader interaction, Hyland's twofold model is based on the observation that authors of academic texts express their viewpoints with regard to (1) the subject matter of the text and (2) its readers, i.e. other members of the academic community. Therefore, as illustrated in Figure 1 below, the model embraces two broad categories of "interactional" resources: stance and engagement. ${ }^{5}$

Fig. 1. Hyland's model of stance as part of interaction in academic writing [Hyland 2005b: 177]

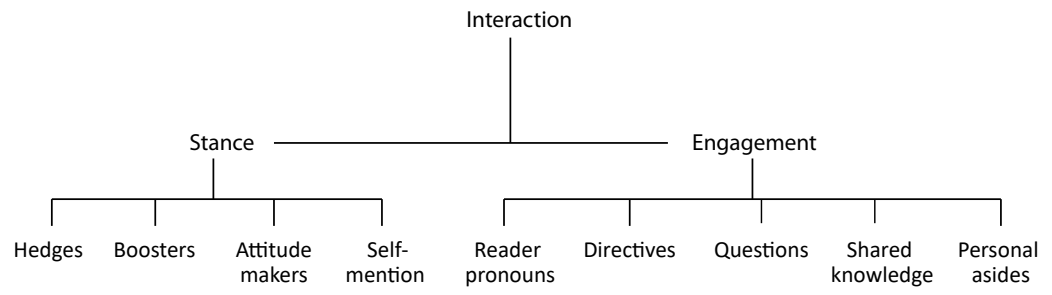

As suggested by the term "stance," it is a notion that falls within the category of viewpoint, while the notion of engagement pertains to the resources employed by writers to relate to their audiences with regard to the positions and arguments advanced in the text [Hyland 2005b: 176]. It must be noted, however, that the boundary between the notions of stance and engagement is rather blurred and, since one linguistic form can be used to signal the author's viewpoint and engage the reader at the same

4 The conceptual framework of Cognitive Linguistics, along with the CG notion of viewpoint, briefly outlined in section 2, would, admittedly, offer a more comprehensive and more "sensitive" methodology for the analysis of viewpoint phenomena. However, given that the main aim of the present study is to justify the need for investigating viewpoint in translated academic prose and that elaborating a cognitive model of the category suited specifically to the study of academic discourse would go beyond the scope of this article, Hyland's "ready-made" model will be used instead, also because it has already been broadly applied in research on original (as opposed to translated) academic texts.

5 Cf. Hyland [2005a], where stance and engagement, the two types of interactional resources, are contrasted with interactive resources, together representing the "metadiscourse" of academic writing. 
time, it is argued that the two categories should rather be treated as "two sides of the same coin" [Hyland 2005b: 174]. With this caveat in mind, the following discussion will be limited to Hyland's category of stance, which is taken to correspond to the notion of viewpoint. ${ }^{6}$

On Hyland's model, the author's viewpoint is communicated in academic discourse by four types of linguistic resources: hedges, boosters, attitude markers, and self-mentions. As indicators of the author's conviction about the reliability of a claim, hedges and boosters represent the epistemic dimension of viewpoint, with hedges signaling the writer's limited confidence. Typical hedges include modal verbs and adverbial expressions, as in examples (1) and (2) respectively, but also certain "other communication verbs" (Biber et al. 1999: 667), such as indicate, imply or suggest, which denote tentative claims, as in (3):

(1) The use of gestures may be more beneficial for those in the later stages of the disease... ${ }^{7}$

(2) He was arguably his generation's greatest exponent of...

(3) This suggests a lexical influence in perceptual learning of speech.

Hedging expressions may also be attributed a reader-engagement function, since the viewpoint that they express can simultaneously be deployed "to recruit his or her interest and assent to claims and meet expectations of deference, modesty and negotiation" (Hyland 1998: 254). By contrast, boosters signal the author's increased conviction that a statement is true, as in:

(4) Of course, the ideal number of repetitions necessary is influenced by a variety of...

(5) Without a doubt, this is what defines the essence of Caravaggio's rebellion and genius...

6 Although "stance" has become a common term in studies on the subjective aspects of meaning in academic writing, it is often defined as "viewpoint." Cf., e.g., Bruce's [2016: 13] definition of stance: "the overall viewpoint or position taken by a writer in relation to the issue or proposition". In the present article, the term "viewpoint" is used, as it seems to have gained wider currency in research on translation and language in general.

7 Examples (1-12) come from the academic section of the Corpus of Contemporary American English [Davies 2008]; bold added. 
(6) Our research on the autonomic system clearly shows that functional neural networks are...

Boosters also "stress shared information, group membership, and engagement with readers" (Hyland 2005b: 179).

Attitude markers signal the author's viewpoint with respect to affect and evaluation. The typical attitudes conveyed by the linguistic resources in this category include surprise, expectation, (dis)agreement, (dis)approval, (un)importance (cf. Hyland 2005b: 180), and the linguistic expressions that perform this function include adjectives and adverbs, as in the following examples:

(7) Not surprisingly, research studies have linked individualized instruction...

(8) It is worth noting that many studies have identified these five sounds as...

(9) One important point that can be inferred from this finding is that...

Although attitude markers can express both evaluations and personal feelings, evaluative judgements seem to be more frequent and play a more prominent role in academic discourse than emotion-laden expressions, which are rather rare [Hyland 2005b: 175].

The last component of the category of viewpoint in Hyland's model is self-mention, which pertains to the presence or absence of expressions referring to the author of the text, such as personal pronouns or, in languages which have them, inflectional affixes on verbs. Importantly, the use or avoidance of explicit author reference generally results from the writer's conscious decision to adopt a particular viewpoint [Hyland 2005b: 181; Hyland 2014: 104]. Thus, examples (10) and (11) below illustrate contrasting viewpoints in terms of self-mention, with, respectively, backgrounded and foregrounded authorial agentivity:

(10) The present study was restricted to self-reported smoking data.

(11) To ensure consistency among sites, we restricted the data from...

It can be argued that the different viewpoints reflected in (10) and (11) resemble the distinction between external third-person narration and subjective first-person narration in literary prose. The author reference in (11) must be, however, distinguished from the use of the first-person plural in such examples as: 
(12) one of these types occurs in pure form, as we will see in section 2.

Whereas (11) is a genuine instance of self-mention, i.e. the pronoun we refers to the actual five authors of the text, (12) represents the so-called inclusive we; the text was authored by one person only, with the plural pronoun referring to the author and the reader. According to Hyland [2005b: 182], the inclusive we signals that the writer and the reader are viewed as members of the same academic community, with similar interests and goals. Although the inclusive we may, formally, be classified as a device of reader engagement, it is arguably primarily a marker of the writer's viewpoint; after all, it indicates that the writer has decided to view the reader as a partner in the research process described in the text. Thus, just as the choice between authorial self-reference and an impersonal construction brings out or obscures the author's role in the reported research process, so through the use or avoidance of the inclusive we authors can "either highlight or downplay the presence of their readers and themselves" [Hyland 2014: 102].

\section{Case study}

The aim of this section is to examine a number of passages from the English original and the Polish translation of John R. Taylor's Cognitive Linguistics monograph Linguistic Categorization with a view to illustrating the types of viewpoint shifts that can occur in translation of an academic text. The analysis draws on Hyland's model as outlined in the previous section. The material has been divided into three categories: shifts in epistemic viewpoint (related to the use of hedging and boosting devices), shifts in attitude, and changes in patterns of authorial self-mention. For ease of analysis, the Polish examples are provided along with literal English back-translations put in brackets.

\subsection{Epistemic viewpoint}

As noted in section 3, the typical linguistic resources communicating the author's epistemic viewpoint in academic discourse include adverbials and verbs signaling the author's commitment to a claim. The following discussion will therefore mainly focus on these two categories of expressions. 
One of the epistemic adverbs recurring in the text under analysis is clearly, which has a boosting function with respect to the statement with which it occurs. More precisely, it expresses the author's increased confidence in the statement. ${ }^{8}$ Out of the 30 occurrences with this epistemic function in the source text, nine cases $(30 \%)$ involve a semantic change in the Polish translation that consists in downtoning, i.e. decreasing the author's commitment to the claim being made. This type of viewpoint shift is illustrated by examples (13) and (14) below, where clearly functions as a sentence adverb in the source text, thereby boosting the whole statement:

(13E) Clearly, ${ }^{9}$ the interaction of the relationships of componentiality and instantiation may result in a number of alternative, and equally valid analyses of a given linguistic expression. (p. 199)

(13P) Wzajemne oddziaływanie związków składnikowości i uszczegółowienia powoduje czasem powstanie kilku odmiennych, choć równie uzasadnionych analiz danego wyrażenia językowego; (p. 271)

[The mutual interaction of the relationships of componentiality and instantiation sometimes causes the emergence of alternative, though equally justified analyses of a given linguistic expression]

(14E) The reason is, clearly, that monotony is not usually measured in terms of seconds and minutes, neither can human beings, with their limited life span, perceive monotony in the succession of centuries and millennia. (p. 201)

(14P) Wynika to stąd, że monotonii nie mierzy się na ogół w sekundach czy minutach, ani - z racji ograniczonej długości ludzkiego życia - w stuleciach i tysiącleciach. (p. 275)

8 As pointed out by Olohan [2004: 196], it is more accurate to regard boosting (or intensifying) and hedging (or downtoning) as functions of the "text producer, not as functions of the lexical items themselves", which is tantamount to treating them as markers of the author's viewpoint.

9 In each example, the relevant expression has been highlighted in bold (not in the original). 
[This follows from the fact that monotony is generally not measured in seconds or minutes or - due to the limited human lifespan - in centuries and millennia]

Epistemic downtoning, brought about by an omission of the adverb clearly in translation, is also evident in example (15), where the adverb modifies the verb show in the English text. While the adverb strengthens the statement about the findings of a discussion in the source text $(15 \mathrm{E})$, the Polish translation (15P) displays a somewhat lower level of definiteness of the claim due to the lack of a similar verb-boosting element.

(15E) The discussion clearly showed that the family of sounds comprising the phoneme category cannot be characterized in terms of a conjunction of categorial features. (p. 230)

(15P) Analiza wykazała, że rodziny dźwięków obejmującej kategorię fonemu nie można opisywać jako połączenia cech kategorialnych. (p. 312)

[The analysis showed that the family of sounds comprising the phoneme category cannot be described as a conjunction of categorial features]

This type of downtoning through omission also occurs with other adverbs and other communication verbs in the source text. For example, in (16E) the adverb strongly strengthens the otherwise tentative claim expressed by the verb suggest, while the claim formulated in (16P) is more hypothetical.

(16E) This strongly suggests that focal colours are perceptually and cognitively more salient than non-focal colours. (p. 11)

(16P) Wyniki te skłaniają do przypuszczenia, że barwy bazowe są percepcyjnie i poznawczo bardziej wyraziste niż niebazowe. (p. 32)

[These encourage one to suppose that focal colours are perceptually and cognitively more salient than non-focal [ones]]

However, not all instances of lowering the certainty level of a statement in translation result from an omission of the adverb. In example (17), the Polish translation includes a hedging expression (wydaje się 'it seems'), which has been introduced into the text instead of a boosting element. 
(17E) Clearly, a natural number must be either odd or even; one even number cannot reasonably be considered more even than another. (p. 68)

(17P) Wydaje się bezsporne, że liczba naturalna musi być parzysta lub nieparzysta, a jedna liczba parzysta nie powinna być uważana za bardziej parzystą od drugiej. (p. 103)

[It seems unquestionable that a natural number must be odd or even, and one even number should not be considered more even than another.]

It is worth noting that the epistemic viewpoint marked in (17E), and in the other examples, could have been easily retained in the Polish translation through the use of a boosting expression, such as niewatpliwie ('undoubtedly') or nie ulega watwpliwości ('without doubt'), as was done in the remaining instances of the use of clearly in the English source text.

Epistemic viewpoint shifts of the opposite character take place when a hedging adverbial in the source text is left without a hedging element in the translation. In the text examined here, this is sometimes the case with the English adverb arguably, as in examples (18) and (19).

(18E) Arguably, most legal decisions have to do, essentially, with the categorization of entities on the fuzzy borders of natural categories. (p. 72)

(18P) Większość rozstrzygnięć prawnych polega $\mathrm{w}$ istocie na kategoryzacji elementów położonych na rozmytych granicach kategorii naturalnych. (p. 108)

[Most legal decisions essentially consist in the categorization of entities located at the fuzzy borders of natural categories.]

(19E) Arguably, the central sense of Italian sopra is... (p. 120)

(19P) Centralne znaczenie włoskiego sopra jest... (p. 170)

[The central sense of Italian sopra is...]

In such instances, the Polish text presents an unhedged and therefore a more definite claim, so that this type of viewpoint shift in translation may be regarded as boosting.

Apart from hedging and boosting adverbials, shifts in epistemic viewpoint may also be observed in connection with the use of communication verbs themselves. A good example here is the English verb suggest, which is one of the commonly used communication verbs in the humanities and 
social sciences [cf. Hyland 2010: 123] and, as noted earlier, it communicates a rather tentative statement. There are several instances where a claim made with this verb receives more credibility in the Polish translation, as in examples (20) and (21):

(20E) As the examples given suggest, the notion of basic level term is generally understood in connection with nominal categories. But the construct is applicable to other kinds of concept. (p. 49)

(20P) Jak wynika z podanych przykładów, koncepcja terminu poziomu podstawowego kojarzy się zwykle z kategoriami rzeczownikowymi. Koncepcję tę można jednak stosować do innych typów pojęć. (p. 79)

[As follows from the examples given, the notion of a basic level term is usually associated with nominal categories. This notion can, however, be applied to other types of concepts.]

(21E) This state of affairs, I have suggested, is by no means unusual; (p. 74)

(21P) Jak wspomnialem, sytuacja taka nie jest bynajmniej niezwykła; (p. 110)

[As I mentioned, such a situation is by no means unusual;]

Again, it must be noted that the translator of this text seems to be aware of the tentative character of the claims communicated with the use of suggest. This is evident in the translations of most of the other-sometimes quite similar - statements with this verb in the English original, as in (22E) below, where the epistemic boosting through the use of the verb wspomniatem ('I mentioned') is compensated for by the introduction of a hedging element (zapewne 'probably') later on in the sentence.

(22E) I suggested earlier that high, as a spatial term, has two distinct senses. (p. 102)

(22P) Wspomniałem wcześniej, że wyraz high „wysoki” jako termin przestrzenny ma zapewne dwa odrębne znaczenia. (p. 146)

[I mentioned earlier that the word high, as a spatial term, probably has two distinct senses.]

There are also instances, however, where an originally factual verbal expression, i.e. one presenting a statement as a fact, becomes downtoned 
in translation due to the introduction of an additional lexical element that functions as a hedge. This can be illustrated by examples (23) and (24).

(23E) Katz and Postal (1964: 14) deal with this problem by recognizing two kinds of semantic feature, which they call markers and distinguishers. (p. 34) (23P) Katz i Postal (1964: 14) starają się rozwiązać ten problem identyfikując dwa rodzaje cechy semantycznej: wyznacznik (marker) i wyróżnik (distinguisher). (p. 60)

[Katz and Postal (1964: 14) seek to solve this problem by identifying two kinds of semantic feature: a marker and a distinguisher]

(24E) Our task will be to systematize nevertheless the data in (16)... (p. 111)

(24P) Podejmiemy jednak próbę usystematyzowania danych z przykładu (16)... (p. 158)

[We will, however, make an attempt to systematize the data in example (16)...]

\subsection{Attitude}

Affect and evaluation can be expressed either lexically or grammatically. While the attitudes signaled by typical lexical means, such as (un)importantly, surprising(ly) and as expected, generally seem to be retained in the target text, in some cases of a grammatically expressed attitude, the viewpoint either does not reach the target audience at all or becomes distorted. Consider the following example:

(25E) There does exist in English a family resemblance category embracing precisely these objects - that denoted by the polysemous word buff. (p. 119)

(25P) W języku angielskim istnieje kategoria podobieństwa rodzinnego obejmująca właśnie te obiekty - kategoria, którą określa polisemiczny wyraz buff. (p. 169)

[In the English language there exists a family resemblance category embracing precisely these objects - the category denoted by the polysemous word buff]. 
Passage (25E) illustrates the use of the English emphatic do, whose function in this particular case is to deny an assumption that the preceding part of the text could have reinforced [cf. Greenbaum 1996: 250]. In terms of viewpoint, the emphasis indicates that, according to the author, the situation described in the sentence will not have been expected. By contrast, the Polish translation represents a grammatically (and lexically) unmarked sentence, devoid of any linguistic resources that would point to emphasis or surprise. This type of viewpoint neutralization, whereby the author's affect expressed by the emphatic $d o$ in the source text is removed in translation, can be observed in several other passages, including the following:

(26E) Thus one may readily say We swam for hours on end, but not * We had a swim for hours on end. In this respect, the transitive construction does impose one component of the transitivity schema, namely punctuality. (p. 216)

(26P) Można zatem powiedzieć We swam for hours on end „Pływaliśmy całymi godzinami”, ale nie *We had a swim for hours on end. Konstrukcja przechodnia narzuca tu jeden ze składników schematu przechodniości, a mianowicie krótkotrwałość akcji. (p. 295)

[...The transitive construction imposes here one of the components of the transitivity schema, namely brevity of action.]

One could argue that the translator's decision to remove the emphasis from the Polish translations of passages like (25E) and (26E) stems from the fact that the statements contained therein (i.e. ones concerning the English language) might not be surprising for the Polish reader. This hypothesis, however, must be rejected since there are other passages about English where the author's attitude does reach the target audience, e.g.

(27E) Lakoff's Two dollars are owed by John does seem odd. (p. 188)

(27P) Podany przez Lakoffa przykład Two dollars are owed by John rzeczywiście wydaje się osobliwy. (p. 257)

[The example given by Lakoff Two dollars are owed by John really seems odd.]

A more complex shift than just affect neutralization can be observed in example (28): 
(28E) ... in many cases there does seem to be a natural basis for grouping these entities into discrete categories. (p. 3)

(28P) ... W wielu wypadkach nie byłoby nonsensem doszukiwać się jakiejś naturalnej podstawy grupowania tych obiektów w odrębne kategorie. (p. 21)

[... in many cases it would not be nonsense to strive to find some natural basis for grouping these entities into distinct categories].

Here, the emphatically positive statement in $(28 \mathrm{E})$ turns into a much downtoned claim in (28P) due to the use of the hedge-like nie bytoby nonsensem ('it would not be nonsense'). Moreover, the verb doszukiwać sie 'strive to find' (typically used with reference to situations where something is difficult to find because of its insignificant size or character) and the indefinite pronoun jakiejs' 'some' introduce a hint of a negative attitude, which is entirely absent from the source text.

\subsection{Self-mention}

As Hyland [2014: 102] points out, reference to the author "can [...] be explicit or disguised, with the writer taking responsibility for actions, or avoiding agency by transitivity selections which favour the passive and non-specific subjects." Therefore, as argued in section 3 , it is reasonable to assume that the presence or absence of self-mention in an academic text stems from a conscious decision on the part of the author, thereby reflecting his or her viewpoint.

Although the analyzed text includes numerous instances of explicit authorial self-mention through the use of the personal pronoun $I$ along with verbs in the first-person singular, there are equally numerous cases, particularly (though not exclusively) in the context of endophoric metadiscourse markers, expressions referring to other parts of the same text, where the author has decided to disguise his agency. For many of those agentless passages, however, the Polish translation exposes the author's persona to a lesser or greater degree despite the fact that Polish offers grammatical resources, such as the passive voice or impersonal forms of verbs, that might have been employed to prevent that.

Shifts in self-mention can be divided into several types, depending on the grammatical construction used in the source and target texts. In some cases, the original passive is replaced with the first-person form of a verb, as in (29): 
(29E) As documented in Chapter 6, the notion of prototype has proved especially useful in studies of word meaning. (p. 260)

(29P) Jak wykazywałem w poprzednich rozdziałach, zwłaszcza w rozdziale 6, pojęcie prototypu dowodzi swojej użyteczności przede wszystkim w badaniach nad znaczeniem wyrazów. (p. 350)

[As I demonstrated in the preceding chapters, particularly in chapter 6, the notion of prototype proves its usefulness primarily in studies of the meanings of words].

In other cases, however, an originally passive cross reference is realized by a verb in the first-person plural (or inclusive we) in the Polish translation. This can be illustrated by the following example:

(30E) As will be discussed more fully in the next chapter, perspectivization gradually shades into metonymic extension. (p. 90)

(30P) Perspektywizacja, jak zobaczymy w następnym rozdziale, przechodzi stopniowo w rozszerzenie metonimiczne. (p. 131)

[Perspectivization, as we will see in the next chapter, gradually shades into metonymic extension].

Admittedly, the use of verbs in the first-person plural is a common strategy, at least in the humanities, for endophoric metadiscourse markers in Polish academic texts, which may, at least partially, account for this type of shift in translation. Nevertheless, it is more difficult to account for cases where this shift is accompanied by an omission of a modal verb with a hedging function, which results in the epistemic boosting of a claim in the translation, as in (31):

(31E) School, which can be understood against a number of alternative domains [...] is a case in point. (p. 100)

(31P) Tak właśnie jest z wyrazem szkoła, który interpretujemy w odniesieniu do domeny kształcenia, struktury administracyjnej itd. (p. 143)

[This is precisely the case with the word school, which we interpret against the domains of education, administrative structure, etc.]

Another type of shift in self-mention is related to the use of so-called abstract rhetors [Hyland 1996] in the English source text. The notion 
of abstract rhetor refers to an inanimate, usually abstract, noun in the subject position where one would normally expect a human subject. This "common strategy [...] suggests that the situation described is independent of human agency" [Hyland 1998: 172]. The text under analysis provides numerous examples where an abstract rhetor turns into a direct selfmention in the translation. ${ }^{10}$ Again, the reference to the author becomes explicit in the Polish translation either through the use of a verb in the first-person singular, as in (32P) and (33P):

(32E) The discussion in Chapter 9 emphasized the analogies between the categories of intonation analysis and other meaning-bearing elements of language. (p. 223)

(32P) W rozdziale 9 podkreślalem analogie między kategoriami analizy intonacyjnej a innymi elementami języka będącymi nośnikami znaczenia. (p. 303)

[In chapter 9 I emphasized the analogies between the categories of intonation analysis and other elements of language carrying meaning].

(33E) Chapter 6 presented an analysis of polysemous lexical items in terms of family resemblance categories consisting of sometimes quite extensive chains of distinct though related meanings. (p. 142)

(33P) W rozdziale 6 omawiałem polisemiczne jednostki leksykalne jako kategorie zbudowane na podstawie podobieństwa rodzinnego, obejmujące niekiedy rozległe łańcuchy odrębnych, choć pokrewnych znaczeń. (p. 199)

[In chapter 6 I discussed polysemous lexical items as categories constructed on the basis of family resemblance, consisting of sometimes extensive chains of distinct though related meanings.]

or through the use of the inclusive first-person plural, as in (34P) and (35P):

(34E) The remaining part of this chapter will examine some of the hedges discussed by Lakoff, and discuss their role in structuring categories. (p. 76)

10 This is particularly the case for abstract rhetor nominals denoting the text or its part. For example, as many as $75 \%$ of the original abstract rhetors with the noun chapter turn into first-person (singular or plural) subjects in the Polish translation. 
(34P) W pozostałej części tego rozdziału przyjrzymy się niektórym spośród modulantów omawianych przez Lakoffa oraz zastanowimy się nad wpływem, jaki wywierają one na strukturę kategorii. (p. 114)

[In the remaining part of this chapter we will look at some of the hedges discussed by Lakoff and we will reflect on the effect they have on the structure of categories.]

(35E) This chapter extends the prototype model, so as to render it applicable to a wider range of linguistic data. (p. 99)

(35P) W tym rozdziale rozszerzymy model prototypowy tak, aby objął pełniejszy zakres danych językowych. (p. 142)

[In this chapter we will extend the prototype model so that it accounts for a fuller range of linguistic data.]

Incidentally, example (33) additionally includes an instance of epistemic boosting, effected by the omission of the downtoner quite [cf. Biber et al. 1999: 555-556]. By contrast, some of the other shifts in self-mention of this type involve epistemic downtoning, as illustrated by (36):

(36E) The main burden of the chapter will be, firstly, to demonstrate that... (p. 158).

(36P) W niniejszym rozdziale postaram się przede wszystkim udowodnić, że... (p. 219).

[In the present chapter I will try to demonstrate, first of all, that...]

In the above example, besides bringing the author's agency to the fore, the use of the expression postaram sie ('I will try') slightly diminishes the certainty that the action described by the verb will actually be achieved.

Examples of the opposite kind, those involving a loss of explicit selfmention, are also attested, though they seem to be much less frequent, in the material. This type of de-agentivizing shift can be illustrated by the following example:

(37E) Since English lacks a diminutive, I shall take most of my examples from Italian. (p. 144)

(37P) Ponieważ język angielski pozbawiony jest deminutiwów, większość moich przykładów będzie pochodzić z języka włoskiego. 
[Since the English language is deprived of diminutives, most of my examples will come from the Italian language].

\section{Conclusion}

The brief case study in the preceding section has presented and discussed instances of viewpoint shifts in the translation of an academic text, based on the Polish translation of an English linguistics monograph. The examples can be divided into several types.

The first two types, representing semantic shifts of opposite characters, consist in increasing or decreasing the author's epistemic commitment to a claim made in the text. As shown in examples (13)-(15), (18)-(19), (31) and (33), this may result from an omission of a boosting or hedging expression, typically an adverb, in the process of translation. However, there are also cases with a booster replaced by a hedging expression in the target text or a hedging expression introduced into the target text in place of an originally factual statement, which was illustrated in examples (16)-(17) and (23)-(24), respectively.

Another type of viewpoint shift consists in altering the author's evaluation of information presented in the text. Examples (25)-(26) showed grammatically emphasized statements in the original, indicating the author's evaluation concerning the expectedness of a state of affairs, reduced to attitude-neutral statements in the translation. Additionally, example (28) illustrated a shift from positive expectation in the source text to just a limited possibility in the translation. It is worth noting that a preponderance of the viewpoint shifts identified within these two categories results in the weakening of a claim or attenuation of an evaluation made by the author of the original, usually - though not necessarily - through omission of a linguistic element present in the source text. These findings are consistent with some studies on translation shifts that report patterns of reduced illocutionary force in translation or interpreting [e.g. Monacelli 2006; Wiraszka 2015] and may well reflect the hypothesized universal tendency of translators to simplify the target text, and hence the message, vis-à-vis the original [cf. Baker 1993; Chesterman 2004].

As for the third category of viewpoint shifts, those connected with self-mention, they were mainly illustrated by two types of examples: statements in the passive translated as sentences with first-person singular or first-person plural verbs (examples 29-31) and sentences with 
inanimate subjects (abstract rhetors) translated as sentences with firstperson (singular or plural) subjects (examples 32-36). Importantly, all of them represent shifts from implicit to explicit author reference, with examples of the opposite type (as in 37) being rare. In future studies, it would be interesting to consider this phenomenon in the light of another hypothesized translation universal, i.e. as a peculiar form of explicitation [cf. Blum-Kulka 1986; Pápai 2004].

Despite some quantitative remarks in the previous paragraphs, it must be remembered that the purpose of the analysis was mainly qualitative; it was to show what types of viewpoint shifts may occur in the translation of an academic text. Thus, the above summary of viewpoint phenomena does not allow for any serious quantitative generalizations, nor does it exclude the possibility of other types of viewpoint shifts occurring in the translation of academic texts. Ultimately, changes of the author's viewpoint in translation may depend on the language pair, the direction of translation, the academic discipline represented by the text, and possibly the genre of the translated text, to mention just the most obvious factors. What this study does show, however, is that since academic prose is far from being devoid of markers of authorial viewpoint, the viewpoints expressed in academic texts are liable to various alterations in translation. Given the special function of such texts, this should be a sufficient reason to include the concept of viewpoint in research on the translation of academic writing. The potential lines of future research include corpus-based quantitative analyses of parallel corpora, which could indicate the relative frequencies of viewpoint shifts in the different categories for particular language pairs, genres and disciplines. Such research might be combined with explanatory studies that would account for particular tendencies and inform translator-education curricula.

\section{References}

Aull, L. A., Lancaster, Z. (2014), "Linguistic Markers of Stance in Early and Advanced Academic Writing", Written Communication, 31(2), pp. 151-183, https://doi.org/10.1177/0741088314527055.

Baker, M. (1993), "Corpus Linguistics and Translation Studies: Implications and Applications", in: M. Baker, G. Francis, E. Tognini-Bonelli (eds.), Text and Technology: In Honour of John Sinclair, John Benjamins, Amsterdam-Philadelphia, https://doi.org/10.1075/z.64. 
Baker, M. (1996), "Corpus-based Translation Studies. The Challenges that Lie Ahead", in: H. Somers (ed.), Terminology, LSP and Translation, John Benjamins, Amsterdam, pp. 175-186, https://doi.org/10.1075/btl.18.17bak.

Banfield, A. (1982), Unspeakable Sentences: Narration and Representation in the Language of Fiction, Routledge \& Kegan Paul, Boston.

Biber, D. (2006), "Stance in Spoken and Written University Registers", Journal of English for Academic Purposes, 5(2), pp. 97-116, https://doi.org/10.1016/j. jeap.2006.05.001.

Biber, D., Johansson, S., Leech, G., Conrad, S., Finegan, E. (1999), The Longman Grammar of Spoken and Written English, Longman, London.

Blum-Kulka, S. (1986), "Shifts of Cohesion and Coherence in Translation", in: J. House, S. Blum-Kulka (eds.), Interlingual and Intercultural Communication: Discourse and Cognition in Translation and Second Language Acquisition Studies, Gunter Narr Verlag, Tübingen, pp. 17-35.

Booth, W. C. (1961), The Rhetoric of Fiction, University of Chicago Press, Chicago.

Bosseaux, Ch. (2007), How Does it Feel? Point of View in Translation: The Case of Virginia Woolf into French, Rodopi, Amsterdam-New York, https://doi. org/10.1163/9789401204408.

Bruce, I. (2016), "Constructing Critical Stance in University Essays in English Literature and Sociology", English for Specific Purposes, 42, pp. 13-25, https://doi.org/10.1016/j.esp.2015.10.005.

Charles, M. (2003), ““This Mystery...': A Corpus-based Study of the Use of Nouns to Construct Stance in Theses from Two Contrasting Disciplines", Journal of English for Academic Purposes, 2(4), pp. 313-326, https://doi.org/10.1016/ S1475-1585(03)00048-1.

Chen, Y. (2012), "The Translator's Subjectivity in Popular Science Translation: A Study from the Perspective of Evaluative Shifts", Emerging Research in Translation Studies: Selected Papers of the CETRA Research Summer School. Chesterman, A. (2004), "Beyond the Particular", in: A. Mauranen, P. Kujamaki (eds.), Translation Universals: Do They Exist?, Benjamins, Amsterdam, pp. 33-49, https://doi.org/10.1075/btl.48.04che.

Cierpisz, M. (2007), Kategoria punktu widzenia w języku i narracji literackiej na przyktadzie Lolity Vladimira Nabokowa i jej polskich przektadów, Unpublished $\mathrm{PhD}$ thesis, Jagiellonian University in Kraków.

Dancygier, B., Sweetser, E. (eds.) (2012), Viewpoint in Language: A Multimodal Perspective, Cambridge University Press, Cambridge-New York, https://doi. org/10.1017/CBO9781139084727. 
Dancygier, B. (2017), "Viewpoint Phenomena in Multimodal Communication", Cognitive Linguistics, 28(3), pp. 371-380, https://doi.org/10.1515/ cog-2017-0075.

Davies, M. (2008), The Corpus of Contemporary American English (COCA): 560 Million Words, 1990-present, [online:] https://corpus.byu.edu/ coca/ - 2.02.2020.

Ehrlih, S. (1990), Point of View: A Linguistic Analysis of Literary Style, Routledge, London-New York.

Englebretson, R. (2007), "Grammatical Resources for Social Purposes: Some Aspects of Stancetaking in Colloquial Indonesian Conversation", in: R. Englebretson (ed.), Stancetaking in Discourse: Subjectivity, Evaluation, Interaction, John Benjamins, Amsterdam-Philadelphia, pp. 69-110, https://doi. org/10.1075/pbns.164.05eng.

Foolen, A., Yamaguchi, T. (2016), "Perspective: Kawabata's Beauty and Sadness and Its Translations into English, German, and Dutch", in: B. Dancygier, W.-L. Lu, A. Verhagen (eds.), Viewpoint and the Fabric of Meaning, De Gruyter Mouton, Berlin-Boston, pp. 191-213, https://doi. org/10.1515/9783110365467-009.

Fowler, R. (1986), Linguistic Criticism, Oxford University Press, Oxford-New York.

Gray, B., Biber, D. (2012), "Current Conceptions of Stance", in: K. Hyland, C. Sancho Guinda (eds.), Stance and Voice in Written Academic Genres, Palgrave Macmillan, Basingstoke-New York, pp. 15-33, https://doi. org/10.1057/9781137030825_2.

Greenbaum, S. (1996), The Oxford English Grammar, Oxford University Press, Oxford-New York.

Guilbeault, D. (2017), "How Politicians Express Different Viewpoints in Gesture and Speech Simultaneously", Cognitive Linguistics, 27(3), pp. 417-447, https://doi.org/10.1515/cog-2016-0086.

Hyland, K. (1996), "Writing Without Conviction? Hedging in Science Research Articles", Applied Linguistics, 17(4), pp. 433-454, https://doi.org/10.1093/ applin/17.4.433.

Hyland, K. (1998), Hedging in Scientific Research Articles, John Benjamins Publishing, Amsterdam-Philadelphia, https://doi.org/10.1075/pbns.54.

Hyland, K. (2005a), Metadiscourse: Exploring Interaction in Writing, Continuum, London-New York. 
Hyland, K. (2005b), "Stance and Engagement: A Model of Interaction in Academic Discourse", Discourse Studies, 7(2), pp. 173-92, https://doi. org $/ 10.1177 / 1461445605050365$.

Hyland, K. (2010), "Constructing Proximity: Relating to Readers in Popular and Professional Science", Journal of English for Academic Purposes, 9(2), pp. 116-127, https://doi.org/10.1016/j.jeap.2010.02.003.

Hyland, K. (2012), "Undergraduate Understandings: Stance and Voice in Final Year Reports”, in: K. Hyland, C. Sancho Guinda (eds.), Stance and Voice in Written Academic Genres, Palgrave Macmillan, Basingstoke-New York, pp. 134-150, https://doi.org/10.1057/9781137030825_9.

Hyland, K. (2014), "Disciplinary Discourses: Writer Stance in Research Articles", in: C. N. Candlin, K. Hyland (eds.), Writing: Texts, Processes and Practices, Routledge, London-New York, pp. 91-121, https://doi. org/10.4324/9781315840390-6.

Hyland, K., Sancho Guinda, C. (eds.), (2012), Stance and Voice in Written Academic Genres, Palgrave Macmillan, Basingstoke-New York, https://doi. org/10.1057/9781137030825.

Kranich, S. (2011), "To Hedge or Not to Hedge: The Use of Epistemic Modal Expressions in Popular Science in English Texts, English-German Translations, and German Original Texts", Text \& Talk - An Interdisciplinary Journal of Language, Discourse \& Communication Studies, 31(1), pp. 77-99, https:// doi.org/10.1515/text.2011.004.

Langacker, R. W. (1987), Foundations of Cognitive Grammar. Vol. 1: Theoretical Prerequisites, Stanford University Press, Stanford.

Lantacker, R. W. (2008), Cognitive Grammar: A Basic Introduction, Oxford University Press, Oxford-New York, https://doi.org/10.1093/acprof:o so/9780195331967.001.0001.

Lewandowska-Tomaszczyk, B. (2010), "Re-conceptualization and the Emergence of Discourse Meaning as a Theory of Translation", in: B. Lewandowska-Tomaszczyk, M. Thelen (eds.), Meaning in Translation, Peter Lang, Frankfurt a. Main, pp. 105-147, https://doi.org/10.3726/978-3-653-00940-8.

Lu, W.-L., Verhagen, A. (2016), "Shifting Viewpoints: How Does that Actually Work across Languages? An Exercise in Parallel Text Analysis", in: B. Dancygier, W.-L. Lu, A. Verhagen (eds.), Viewpoint and the Fabric of Meaning, De Gruyter Mouton, Berlin-Boston, pp. 169-190, https://doi. org/10.1515/9783110365467-008. 
McIntyre, D. (2006), Point of View in Plays: A Cognitive Stylistic Approach to Viewpoint in Drama and Other Text-types, John Benjamins, AmsterdamPhiladelphia, https://doi.org/10.1075/lal.3.

Monacelli, C. (2006), "Implications of Translational Shifts in Interpreter-mediated Texts", Pragmatics, 16(4), pp. 457-473, https://doi.org/10.1075/ prag.16.4.03mon.

Olohan, M. (2004), Introducing Corpora in Translation Studies, Routledge, London-New York, https://doi.org/10.4324/9780203640005.

Pápai, V. (2004), “Explicitation. A Universal of Translated Text?”, in: A. Mauranen, P. Kujamaki (eds.), Translation Universals: Do They Exist?, Benjamins, Amsterdam, pp. 143-164, https://doi.org/10.1075/btl.48.12pap.

Pisanski Peterlin, A. (2008), "The Thesis Statement in Translations of Academic Discourse: An Exploratory Study", The Journal of Specialised Translation, 10, pp. 10-22.

Pisanski Peterlin, A. (2010), "Hedging Devices in Slovene-English Translation: A Corpus-Based Study", Nordic Journal of English Studies, 9(2), pp. 171193, https://doi.org/10.35360/njes.222.

Sancho Guinda, C., Hyland, K. (2012), "Introduction: A Context-Sensitive Approach to Stance and Voice", in: K. Hyland, C. Sancho Guinda (eds.), Stance and Voice in Written Academic Genres, Palgrave Macmillan, BasingstokeNew York, pp. 1-11, https://doi.org/10.1057/9781137030825_1.

Scheibman, J. (2002), Point of View and Grammar: Structural Patterns of Subjectivity in American English Conversation, John Benjamins, AmsterdamPhiladelphia, https://doi.org/10.1075/sidag.11.

Silver, M. (2003), "The Stance of Stance: A Critical Look at Ways Stance Is Expressed and Modeled in Academic Discourse", Journal of English for Academic Purposes, 2(4), pp. 359-374, https://doi.org/10.1016/ S1475-1585(03)00051-1.

Simpson, P. (1993), Language, Ideology and Point of View, Routledge, LondonNew York, https://doi.org/10.4324/9780203136867.

Tabakowska, E. (1993), Cognitive Linguistics and Poetics of Translation, Gunter narr Verlag, Tubingen.

Tabakowska, E. (2004), "O językowych wyznacznikach punktu widzenia”, in: J. Bartmiński, S. Niebrzegowska-Bartmińska, R. Nycz (eds.), Punkt widzenia w jezzyku $i$ w kulturze, Wydawnictwo UMCS, Lublin.

Tabakowska, E. (2014), "Point of View in Translation. Lewis Carroll's Alice in Grammatical Wonderlands", in: C. Harrison, L. Nuttall, P. Stockwell, W. Yuan 
(eds.), Cognitive Grammar in Literature, John Benjamins, Amsterdam-Philadelphia, pp. 101-116, https://doi.org/10.1075/lal.17.07tab.

Taylor, J. R. (1995), Linguistic Categorization, $2^{\text {nd }}$ Edition, Clarendon Press, Oxford.

Taylor, J. R. (2001), Kategoryzacja w języku, (Translated by A. Skucińska), Universitas, Kraków.

Thompson, S. E. (2003), "Text-Structuring Metadiscourse, Intonation and the Signalling of Organisation in Academic Lectures", Journal of English for Academic Purposes, 2(1), pp. 5-20, https://doi.org/10.1016/ S1475-1585(02)00036-X.

Tse, P. (2012), "Stance in Academic Bios", in: K. Hyland, C. Sancho Guinda (eds.), Stance and Voice in Written Academic Genres, Palgrave Macmillan, Basingstoke-New York, pp. 69-84, https://doi.org/10.1057/9781137030825_5.

Warchał, K., Łyda, A. (2009), "Interpreting Stance: Epistemic Modality Markers in Polish-English Consecutive Interpreting", in: M. Wysocka (ed.), On Language Structure, Acquisition and Teaching: Studies in Honour of Janusz Arabski on the Occasion of His $70^{\text {th }}$ Birthday, Uniwersytet Śląski, Katowice, pp. 221-242.

Wiraszka, Ł. (2015), Kategoria punktu widzenia w przekładzie ustnym z perspektywy językoznawstwa kognitywnego: W relacji język polski-język angielski, Universitas, Kraków.

\section{Abstract}

This article employs the concept of viewpoint, also referred to as point of view or stance, to offer a short case study of semantic shifts in the translation of academic writing. Drawing on a model of the concept developed specifically for research into the subjective aspects of academic prose, the study seeks to show what viewpoint shifts can occur in translation, based on an analysis of a Cognitive Linguistics monograph translated from English into Polish. The examples, supplemented with English back-translation glosses, illustrate several types of viewpoint shifts taking place in translation, such as increasing or decreasing the author's commitment to a claim, the removal of author emphasis from the text, and shifts from implicit to explicit author mention. Given that academic discourse has ceased to be regarded as objective description of facts, and based on the assumption that the linguistic resources connected with hedging, evaluation and (avoidance of) self-mention are consciously deployed by 
authors of academic texts, it is suggested that viewpoint phenomena may represent a valuable research area for the strand of translation studies concerned with academic writing.

Keywords: viewpoint, stance, self-mention, linguistics, academic discourse 